\title{
MILK AS AN ESSENTIAL SOURCE OF IODINE IN LATVIAN POPULATION
}

\author{
Lolita Vija Neimane ${ }^{1, \#}$, Ilze Konrade ${ }^{2,8}$, Gita Avotina ${ }^{3}$, Aneka Klavin,a ${ }^{4}$, \\ Jelena Zagorska ${ }_{7}^{5}$, Inese Martinsone ${ }^{2}$, Vinita Cauce ${ }^{6}$, leva Kalere ${ }^{3}$, \\ Vincenzo Baylon ${ }^{7}$, and Aivars Lejnieks ${ }^{2,8}$ \\ ${ }^{1}$ Department of Sports and Nutrition, Faculty of Rehabilitation, Rīga Stradinš University, Rīga, LV-1007, LATVIA \\ 2 Department of Internal Diseases, Rīga Stradinš̌ University, Rīga, LV-1038, LATVIA \\ ${ }^{3}$ Residency Development Programme, University of Latvia, Rīga, LV-1586, LATVIA \\ ${ }^{4}$ Laboratory of Hygiene and Occupational Diseases, Rīga Stradiňš University, Science Hub "Kleisti”, Rīga, LV-1067, LATVIA \\ ${ }^{5}$ Faculty of Food Technology, Latvia University of Agriculture, Jelgava, LV-3001, LATVIA \\ ${ }^{6}$ Department of Physics, Rīga Stradinš̌ University, Rīga, LV-1007, LATVIA \\ 7 Institute of Health \& Scientific Research, Saint James Hospital, Sliema, SLM 1807, MALTA \\ ${ }^{8}$ Rīga East University Hospital, 3 Linezera Str., Rīga, LV-1038, LATVIA \\ \# Corresponding author, Iolita.neimane@ inbox.Iv
}

Contributed by Aivars Lejnieks

\begin{abstract}
Milk and dairy products are studied as alternative iodine sources, because salt iodisation is controversial due to high salt consumption leading to cardiovascular diseases. However, the iodine concentration in milk markedly varies. This study evaluated the iodine concentration in cow's milk available in the Latvian market. lodine and fat concentration was analysed with a spectrophotometer "Varian Cary 50" based ISO 2446:2008 in 20 milk samples. Data from the Central Statistical Bureau and survey among pregnant women were used to analyse milk product consumption and its impact on iodine status. Average iodine concentration in milk samples was 457.6 (179.6) $\mu \mathrm{g} / \mathrm{L}$, winter samples had a higher concentration of iodine than summer samples: 563.4 (329.6) $\mu \mathrm{g} / \mathrm{L}$ and $469.2(162.0) \mu \mathrm{g} / \mathrm{L}$, but this is not statistically significant $\mathrm{p}<0.05$. lodine concentration in skimmed milk was $490 \mu \mathrm{g} / \mathrm{L}$, milk with the reduced fat content $501.7(174.8) \mu \mathrm{g} / \mathrm{L}$, and whole milk - 422.6 (192.1)1 $\mu \mathrm{g} / \mathrm{L}$. Milk consumption decreased from 2002 to 2014, while yogurt and cheese consumption increased. Higher consumption of milk and milk products was related to higher urinary iodine concentration $\rho=0.115 ; p=0.003$. Milk and milk products are an important iodine source in Latvia and their consumption should be promoted.
\end{abstract}

Key words: iodine concentration in milk, milk products, skimmed milk, iodine deficiency.

\section{INTRODUCTION}

Iodine is an essential trace element for humans and animals, and is incorporated into thyroid hormones such as thyroxine and triiodothyronine, which have multiple functions in energy metabolism and growth, as a transmitter of nervous stimuli and as an important factor for brain development (Flachowsky et al., 2013). Adequate amount of dietary iodine is essential for the production of thyroid hormones. Recent studies have shown that even a mild degree of iodine deficiency affects cognitive function and school performance in clinically euthyroid school-aged children (Soriguer et al., 2011). In order to ensure metabolic processes, the recommended daily dose of dietary iodine intake according to the World Health Organisation (Anonymous, 2014) is:
1-8 years olds $-90 \mu \mathrm{g} / \mathrm{d} ; 9-13$ years $-120 \mu \mathrm{g} / \mathrm{d} ; 14$ years and older $-150 \mu \mathrm{g} / \mathrm{d}$; pregnant and lactating women - $250 \mu \mathrm{g} / \mathrm{d}$; women of reproductive age (15-49 years) $150 \mu \mathrm{g} / \mathrm{d}$.

Iodine deficiency is a public health problem in 54 countries, including both developed and developing countries. (Hernando et al., 2015). A mild iodine deficiency persists in approximately $50 \%$ of continental Europe (Hernando et al., 2015). To evaluate the situation in Latvia, a nationwide cross-sectional school-based cluster survey on iodine deficiency disorders was conducted in 2000. The median urinary iodine concentration (UIC) $59 \mu \mathrm{g} / \mathrm{L}$ was indicative of mild iodine deficiency; severe iodine deficiency (UIC 59 $\mathrm{mg} / \mathrm{L})$ was observed in $19.2 \%(\mathrm{n}=115)($ Selga et al., 2000). 
In a ten-year follow-up study, the median inter-seasonal creatinine standardised urinary iodine concentration in Latvian schoolchildren was $107.3 \mu \mathrm{g} / \mathrm{g} \mathrm{Cr}$ (Creatinine), a value within the lower normal range. However, various stages of iodine deficiency were observed in $49 \%$ of Latvian schoolchildren, especially in spring (Konrade et al., 2014).

A mandatory salt iodisation programme in Latvia has not been introduced, but voluntary salt fortification was widely promoted. Nonetheless, WHO recommends that the daily salt intake is less than $5 \mathrm{~g}$ in adults due to association with high blood pressure and increased risk of heart disease and stroke (Anonymous, 2014). Reducing salt consumption requires a higher added iodine amount, which may result in displeasing organoleptic properties. Thus, iodised salt cannot be considered to be a sufficient iodine source.

Because iodine intake is determined by the diet, naturally iodine rich foods should be considered. Seawater contains high concentrations of iodine (Pessah-Pollack et al., 2014), therefore seaweed and other foods of marine origin have been suggested to supply adequate iodine intake. However, these foods are relatively rare in everyday Latvian meals (Grīnberga et al., 2015).

Iodine deficiency used to be widespread in Britain with high rates of goitre, in many areas even until the 1960s. (Phillips, et al., 1997). In the 1930s, iodine supplementation of livestock was begun to improve reproductive performance and lactation, thereby increasing iodine content in milk. To date iodine in consumer milk is derived from several sources: natural iodine content of the feed and drinking water given to cows; vitamin and mineral feed additives that enrich cow diets; and from veterinary drugs and udder and milking machine disinfectants (Brzoska et al., 2009). Thus, milk and milk products such as kefir, yoghurt, and cottage cheese became excellent iodine sources. At the same time, government policies aimed to increase milk and milk product consumption, e.g. in the free school milk programme. As a result, dietary iodine intake rose from $80 \mu \mathrm{g}$ to $255 \mu \mathrm{g}$ daily between 1952 and 1982 (Phillips, 1997).

Iodine concentration in milk displays a marked variation from one sample to another and changes have occurred over time. Furthermore, organic milk has been shown to contain less iodine (Rasmussen et al., 2000; Dahl et al., 2003; Bath et al., 2012; Kohler et al., 2012; Payling et al., 2015).

The aim of the paper is to evaluate the role of milk in preventing possible iodine deficiency in Latvia, in regard to planning school milk programmes.

\section{MATERIALS AND METHODS}

Samples used in this study were selected at random from various milk-producing regions throughout of Latvia. We analysed 20 samples of milk from six commercial brands and from nine farms in Latvia. The milk was purchased in commercial establishments - supermarkets and farmers' markets. The following data were obtained for each sample: season of purchase (i.e. winter: November - January, summer: June - August), expiration date, fat content of milk: whole $(3.0-4.5 \%)$, reduced fat $(2.0-2.5 \%)$, and skimmed $(0.05-0.5 \%)$. Before testing the milk samples were stored in a freezer at $-6{ }^{\circ} \mathrm{C}$. Prior to iodine analyses, the milk samples were defrosted at room temperature; conditions in the laboratory were $23{ }^{\circ} \mathrm{C}$ temperature with $50 \%$ relative air humidity and atmospheric pressure $780 \mathrm{mmHg}$. For determination of iodine deficiency in raw milk samples, the kinetic colorimetric method based on the Sandell-Kolhoff reaction catalysed by iodine was used (Sandell and Kolthoff, 1937; Shelor and Dasgupta, 2011; Gasior et al., 2013). Milk samples were mineralised with ammonium persulfate and analysed using a spectrophotometer "Varian Cary 50". The method was validated using the milk reference material ERM-BD 150 (European Commission, Institute for Reference Material and Measurements) with reference value 1.73 $\mu \mathrm{g} / \mathrm{g}$. Method recovery efficiency, determined by the standard addition method, was $106 \%$, which implies that some included components showed higher results than the real value. This might have been due to sample preparation, by incomplete separation or filtration of some proteins causing interference with absorption readings. However, a $6 \%$ increase of values is small and does not affect the overall pattern of iodine concentration in milk.

To analyse the milk as a possible source of iodine in the diet, it is necessary to identify the milk and milk product consumption patterns in the population. Data of milk product consumption per household member per year were obtained from the Central Statistical Bureau of Latvia.

The impact of consumption of milk products on iodine status was analysed using data from a survey among pregnant women in Latvia, conducted in 2013. A total of 685 participants were included in the present data analysis. Median value and interquartile range (IQR) of urinary iodine concentration as well as proportion of pregnant women having UIC below $150 \mu \mathrm{g} / \mathrm{g} \mathrm{Cr}$ (Creatinine) was estimated in subgroups defined by the consumption of milk and milk products. Association between milk product consumption and UIC was tested by Spearman's rank correlation; the chi-square $\left(\chi^{2}\right)$ test for trends was used to compare proportion of respondents with UIC below $150 \mu \mathrm{g} / \mathrm{g}$ Cr according to the categories of milk and milk products consumption.

The statistical analysis was performed with the Statistical Package for the Social Sciences (SPSS), version 20.0 for Windows; SPSS, Chicago, IL.

\section{RESULTS}

Twenty milk samples were analysed. Of these, 55\% $(\mathrm{n}=$ 11) were whole milk samples with fat content of $3.0-4.5 \%$, $35 \%(\mathrm{n}=8)$ were semi-skimmed milk samples with fat content $2.0-2.5 \%$ were and $5 \%(\mathrm{n}=1)$ were skimmed milk samples with fat content $0.05-0.5 \%$. The iodine concentration was greater in the reduced fat milk than the whole milk, respectively, 501.7 (174.8) $\mu \mathrm{g} / \mathrm{L}$ and 422.6 (192.1) $\mu \mathrm{g} / \mathrm{L}$ 
IODINE CONCENTRATION IN WHOLE, REDUCED FAT AND SKIMMED MILK SAMPLES

\begin{tabular}{|c|c|c|c|c|c|c|}
\hline \multirow[b]{2}{*}{ Milk type } & \multirow[b]{2}{*}{ Fat content } & \multirow[b]{2}{*}{$\mathrm{n}$} & \multicolumn{4}{|c|}{ Iodine concentration, $\mu \mathrm{g} / \mathrm{L}$} \\
\hline & & & $\begin{array}{c}\text { Mean (standard } \\
\text { deviation) }\end{array}$ & Geometric mean & Minimal & Maximal \\
\hline Whole & $3.0-4.5 \%$ & 11 & $422.6(192.1)$ & 382.3 & 199.9 & 732.5 \\
\hline Semi-skimmed & $2.0-2.5 \%$ & 8 & $501.7(174.8)$ & 470.8 & 217.4 & 707.7 \\
\hline
\end{tabular}

(Table 1), but this difference was not statistically significant $p<0.05$. The iodine concentration was $490.0 \mu \mathrm{g} / \mathrm{L}$ the skimmed milk sample.

$55 \%(\mathrm{n}=11)$ of the samples were collected in summer and $45 \%(n=9)$ in winter. The winter samples had a higher concentration of iodine than the summer samples: 563.4 (329.6) $\mu \mathrm{g} / \mathrm{L}$ and 469.2 (162.0) $\mu \mathrm{g} / \mathrm{L}$ but this difference was not statistically significant. (Table 2).

Mean iodine concentration in the samples was 457.6 (179.6).

The milk product consumption pattern in Latvia showed that whole milk consumption had decreased by $32 \%$ from $52.01 \mathrm{~L} /$ year in 2002 to $35.24 \mathrm{~L} /$ year in 2014 per one household member per year. Skimmed and reduced fat milk consumption had also decreased, by $46 \%$ from $14.49 \mathrm{~L} /$ year in 2002 to 7.89 L/year in 2014. However, yoghurt consumption had increased by $48 \%$, from $3.11 \mathrm{~kg} /$ year in 2002 to $6.99 \mathrm{~kg} /$ year in 2014. Cheese consumption had also increased, by $48 \%$ from $4.57 \mathrm{~kg} /$ year in 2002 to $6.47 \mathrm{~kg} / \mathrm{year}$ in 2014. Data of the dairy product consumption per household member per year were obtained from the Central Statistical Bureau of Latvia 2014.

In the survey of pregnant women in Latvia, 50.5\% $(\mathrm{n}=346)$ reported consumption of milk and dairy products in the amount of one serving per day; $38.3 \%(n=262)$ consumed two to four servings per day; and the others $(11.2 \%, \mathrm{n}=77)$ admitted rare consumption of milk products - less than once per day. Consumption of milk products was significantly associated with urinary iodine concentration (Fig. 1). Higher consumption of milk and milk products was related to higher UIC (Spearman's correlation coefficient $\rho=$ $0.115 ; p=0.003$ ) Low consumption of milk and milk products by pregnant women caused a UIC below $150 \mu \mathrm{g} / \mathrm{g} \mathrm{Cr}$ (Creatinine) $\left(\chi^{2}\right.$ test for trend $\left.\mathrm{p}=0.042\right)$. Nevertheless, the proportion of UIC below $150 \mu \mathrm{g} / \mathrm{g} \mathrm{Cr}$ (Creatinine) was high even among women $(\mathrm{n}=262)$ consuming $2-4$ servings of milk and milk products per day $-77.9 \%$ (95\% CI $72.5 \%-82.5 \%)$.

Neither UIC nor consumption of dairy products differed between regions of Latvia. (Konrade et al., 2014). However, the strength of the association between consumption of milk products and UIC varied by region. It was the strongest in Zemgale and Latgale, where consumption of milk and milk products was positively correlated with median UIC ( $\rho=$ $0.168 ; p=0.023$ and $\rho=0.191 ; p=0.035$, respectively);
Table 2

IODINE CONCENTRATION IN WINTER AND SUMMER MILK SAMPLES

\begin{tabular}{l|c|c|c|c|c}
\hline \multirow{2}{*}{ Season } & \multirow{n}{*}{} & \multicolumn{4}{|c}{ Iodine concentration, $\mu \mathrm{g} / \mathrm{L}$} \\
\cline { 3 - 6 } & & $\begin{array}{c}\text { Mean (standard } \\
\text { deviation) }\end{array}$ & $\begin{array}{c}\text { Geometric } \\
\text { mean }\end{array}$ & Minimal & Maximal \\
\hline Winter & 9 & $563.4(329.6)$ & 399.0 & 199.9 & 732.5 \\
Summer & 11 & $469.2(162.0)$ & 439.3 & 217.4 & 707.7 \\
Total & 20 & $457.6(179.6)$ & 420.7 & 199.9 & 732.5
\end{tabular}
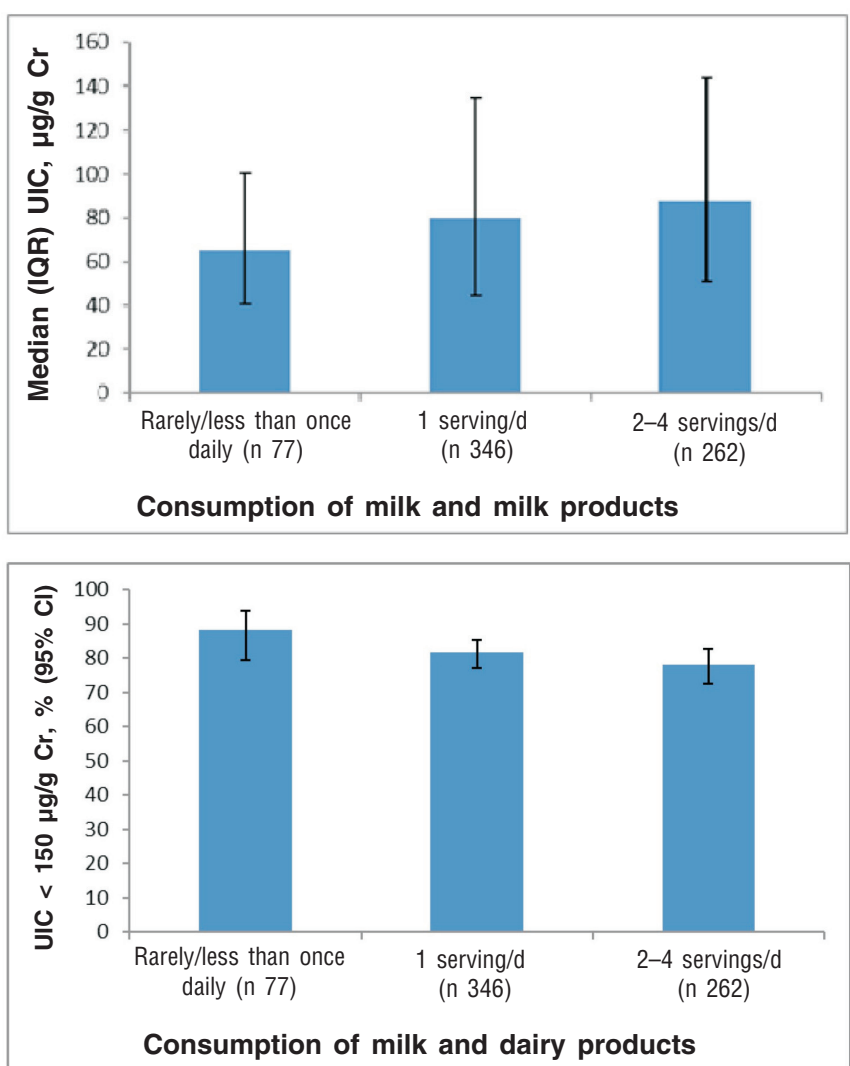

Fig. 1. Association between milk product consumption and urinary iodine concentration. (A) Milk and milk products consumption was positively correlated with median UIC. (B) Milk and milk products consumption was associated with a lower proportion of pregnant women having UIC below $150 \mu \mathrm{g} / \mathrm{g} \mathrm{Cr}$ (Creatinine).

whereas in Kurzeme, there was no association between milk consumption and UIC.

\section{DISCUSSION}

In 2014, the WHO reported that high salt consumption leads to arterial hypertension and cardiovascular diseases in hu- 
mans. Since that time, many alternative sources of iodine other than iodised salt have been studied. Our study confirmed the role of milk as an iodine source, as in other studies (Lamand and Tressol, 1992; Phillips, 1997; Dahl et al., 2003; Pearce et al., 2004; Kohler et al., 2012).

In our study, only one skimmed milk sample was analysed, and thus no conclusions about iodine content in organic milk samples can be made. A higher level of iodine in skimmed milk was found in a study conducted in Spain (Soriguer et al., 2011), but a study from United Kingdom (Payling et al., 2015) and another study from Germany (Kohler et al., 2012) did not find significant differences in iodine concentration between milk types.

This study demonstrates higher iodine concentration in winter milk samples than in the summer milk samples but this was not statistically significant, $p<0.05$. In a study from Germany, significant differences between iodine concentration in autumn and spring milk samples also were not found (Kohler et al., 2012). Similar results were obtained in two studies from the United States (Pennington, 1990; Pearce et al., 2004), one study from the United Kingdom (Phillips, 1997) and one study from France (Lamand and Tressol, 1992). It seems very plausible that differences in milk iodine content between the summer and winter season are due to differences in feeding, for example, by a higher proportion of preserved fodders in winter types of feed rations that contain more iodine (Dahl et al., 2003; Rasmussen et al., 2000).

A large percentage of the Latvian population has a suboptimal iodine intake and is iodine deficient (Konrade et al., 2015). Studies conducted in the United Kingdom, the United States and Italy, areas known for partial coverage of iodised salt, also suggest suboptimal iodine status in pregnant women (Marchioni et al., 2008; Bath et al., 2014; Hollowell et al., 1998). This deficiency can occur during pregnancy, when the maternal need for thyroid hormone increases due to the transfer of iodine and thyroid hormone to the foetus and the increase in renal iodine clearance (Zimmermann et al., 2008). Without a mandatory salt fortification programme or artificial iodisation of cattle food and with a decreasing proportion of food being fortified with iodine, an inevitable outcome is iodine deficiency. New data from Latvia suggest that $11.3 \%(n=66)$ of pregnant women use iodised salt at home, but $42.6 \%(n=248)$ have never used iodised salt at home (Konrade et al., 2015.). The proportions of pregnant women in rural areas of Vidzeme, Latgale, Kurzeme, and Zemgale that have never used iodised salt at home are higher than that in Riga $(40.0 \%, 47.1 \%$, $40.7 \%, 53.7 \%$ and $31.1 \%$, respectively, $p=0.005$ ) (for detailed data see Table 3; unpublished data). A compulsory salt iodisation programme has not been implemented in Latvia and in these conditions very few pregnant women use iodised salt at home, which results in a deficient median creatinine $(\mathrm{Cr})$-standardised urinary iodine concentration (Konrade et al., 2015). There is a need for different iodine sources, preferably in the form of widely consumed foods. Iodine enriched milk has become a major adventitious
Table 3

IODISED SALT CONSUMPTION AT HOME REPORTED BY PREGNANT WOMEN IN REGIONS OF LATVIA (UNPUBLISHED DATA)

\begin{tabular}{l|c|c|c|c|c|c|c|c}
\hline \multirow{2}{*}{ Region } & \multicolumn{8}{|c|}{ Use of iodised salt at home } \\
\cline { 2 - 9 } & \multicolumn{2}{|c|}{ always } & \multicolumn{2}{c}{ sometimes } & \multicolumn{2}{c}{ never } & \multicolumn{2}{c}{ total } \\
\cline { 2 - 10 } & count & $\%$ & count & $\%$ & count & $\%$ & count & $\%$ \\
\hline Riga & 23 & $15.2 \%$ & 81 & $53.6 \%$ & 47 & $31.2 \%$ & 151 & $100 \%$ \\
Vidzeme & 2 & $4.0 \%$ & 28 & $56.0 \%$ & 20 & $40.0 \%$ & 50 & $100 \%$ \\
Latgale & 8 & $7.8 \%$ & 46 & $45.1 \%$ & 48 & $47.1 \%$ & 102 & $100 \%$ \\
Kurzeme & 15 & $12.2 \%$ & 58 & $47.1 \%$ & 50 & $40.7 \%$ & 123 & $100 \%$ \\
Zemgale & 18 & $11.5 \%$ & 55 & $35.3 \%$ & 83 & $53.2 \%$ & 156 & $100 \%$ \\
Total & 66 & $11.3 \%$ & 268 & $46.0 \%$ & 248 & $42.6 \%$ & 582 & $100 \%$
\end{tabular}

source of iodine in many countries in the Northern Europe, as well as in the United Kingdom and the United States (Allen et al., 2006).

The main limitation of the current study is the small milk sample size resulting in lower statistical power. However, they cannot be dismissed, because iodine concentration is highly specific to each region and depends on local policies - such as regulations on the amount of iodine in cow's feed and the use of iodine as a disinfectant for animal welfare improvement. Therefore, information on the iodine concentration in milk in Latvia cannot be drawn directly from larger international studies.

\section{ACKNOWLEDGEMENTS}

This study was supported by and is a part of state research project "Biomedicine". The funders had no role in creation of this article. Authors have no conflict of interest.

\section{REFERENCES}

Allen, L., de Benoist, B., Dary, O., Hurrell, R. (eds.). (2006). Guidelines on Food Fortification with Micronutrients. World Health Organization and Food and Agriculture Organization of the United Nations (WHO/FAO). $341 \mathrm{pp}$.

Anonymous (2014). Sodium intake for adults and children. WHO. Available from: http://www.who.int/nutrition/publications/guidelines/sodium_intake/en/ (accessed 2016 April 18).

Bath, S. C., Walter, A., Taylor, A. (2014). Iodine deficiency in pregnant women living in the South East of the UK: The influence of diet and nutritional supplements on iodine status. Brit. J. Nutr., 111 (9), 1622-1631.

Brzoska, F., Szybinski, Z., Sliwinski, B. (2009). Iodine concentration in Polish milk - variations due to season and region. Endokrynol. Pol., 60 (6), 449-454.

Dahl, L., Opsahl, J. A., Meltzer, H. M., Julshamn, K. (2003). Iodine concentration in Norwegian milk and dairy products. Brit. J. Nutr., 90 (3), 679-685.

Flachowsky, G., Franke, K., Meyer, U., Leiterer, M., Schöne, F. (2013). Influencing factors on iodine content of cow milk. Eur. J. Nutr., 53 (2), 351-365.

Grinberga, S., Dambrova, M., Latkovskis, G., Strele, I., Konrade, I., Hartmane, D., Sevostjanovs, E., Liepinsh, E., Pugovics, O. (2015). Determination of trimethylamine-N-oxide in combination with Lcarnitine and $\gamma$-butyrobetaine in human plasma by UPLC/MS/MS. Biomed. Chromatogr., 29 (11), 1670-1674. 
Hernando, V. U., Anilza, B. P., Hernan, S. T. C. (2015). Iodine deficiency disorders. J. Thyroid Disorders Ther., 172 (4), doi:10.4172/2167-7948.1000172.

Hollowell, J. G., Staehling, N. W., Hannon, W. H., Flanders, D. W., Gunter, E. W., Maberly, G. F., Braverman, L. E., Pino, S., Miller, D. T., Garbe, P. L., DeLozier, D. M., Jackson, R. J. (1998). Iodine nutrition in the United States. Trends and public health implications: Iodine excretion data from National Health and Nutrition Examination Surveys I and III (1971-1974 and 1988-1994). J. Clin. Endocrinol, Metab., 83 (10), 3401-3408.

Kohler, M., Fechner, A., Leiterer, M., Sport, K., Remer, T., Schafer, U., Jahreis, G. (2012). Iodine content in milk from German cows and in human milk: New monitoring study. Trace Elem. Electrolytes, 29 (2), 119-126.

Konrade, I., Kalere, I., Strele, I., Makrecka-Kuka, M., Jekabsone, A., Tetere, E., Veisa, V., Gavars, D., Rezeberga, D., Pīrāgs, V., Lejnieks, A., Dambrova, M. (2015). Iodine deficiency during pregnancy: A national cross-sectional survey in Latvia. Public Health Nutr., 18 (16), 2990-2997.

Konrade, I., Neimane, L., Makrecka, M., Strele, I., Liepinsh, E., Lejnieks, A., Vevere, P., Gruntmanis, U., Pīrāgs, V., Dambrova, M. (2014). A cross-sectional survey of urinary iodine statuss in Latvia. Medicina (Kaunas), 50 (2), 124-129.

Lamand, M., Tressol, J. C. (1992). Contribution of milk to iodine intake in France. Biol. Trace Elem. Res., 32, 245-251.

Marchioni, E., Fumarola, A., Calvanese, A. (2008). Iodine deficiency in pregnant women residing in an area with adequate iodine intake. Nutrition, 24 (5), 458-461.
Payling, L. M., Juniper, D. T., Drake, C., Rymer, C., Givens, D. I. (2015). Effect of milk type and processing on iodine concentration of organic and conventional winter milk at retail: Implications for nutrition. Food Chem., 178, 327-330.

Pearce, E. N., Pino, S., He, X., Bazrafshan, H. R., Lee, S. L., Braverman, L. E. (2004). Sources of dietary iodine: Bread, cows' milk, and infant formula in the Boston area. J. Clin. Endocrinol. Metab., 89 (7), 3421-3424.

Pessah-Pollack, R., Eschler, D. C., Pozharny, Z., Davies, T. (2014). Apparent insufficiency of iodine supplementation in pregnancy. J. Women's Health, 23 (1), 51-56.

Pennington, J. A. T. (1990). Iodine concentrations in US milk: Variation due to time, season, and region. J. Diary Sci., 73 (12), 3421-3427.

Phillips, D. I. (1997). Iodine, milk, and the elimination of endemic goitre in Britain: The story of an accidental public health triumph. J. Epidemiol. Community Health, 51 (4), 391-393.

Rasmussen, L. B., Larsen, E. H., Ovesen, L. (2000). Iodine content in drinking water and other beverages in Denmark. Eur. J. Clin. Nutr., 54 (1), $57-60$

Selga, G., Sauka, M., Gerasimov, G. (2000). Status of iodine deficiency in Latvia reconsidered: Results of nation-wide survey of 587 schoolchildren in the year 2000. IDD (Iodine Deficiency Disorders) Newsletter, 16, 54.

Soriguer, F., Gutierrez-Repiso, C., Gonzalez-Romero, S., Oliveira, G., Garriga, M. J., Velasco, I., Santiago, P., Escobar, G. M., Garcia-Fuentes, E. (2011). Iodine concentration in cow's milk and its relation with urinary iodine concentrations in the population. Clin. Nutr., 30 (1), 44-48.

Zimmermann, M. B., Jooste, P. L., Pandav, C. S. (2008). Iodine deficiency disorders. Lancet, 372, 1251-1262.

Received 9 October 2016

Accepted in the final form 1 November 2017

\section{PIENA PRODUKTU LOMA JODA DEFICİTA TRAUCĒJUMU PROFILAKSĒ}

Piens un piena produkti tiek pētīti kā alternatīvi joda avoti, jo sāls jodēšana ir pretrunīga, tādēḷ ka augsts sāls patēriņš ir saistīts ar kardiovaskulārajām slimībām. Tomēr joda saturs pienā ir l̦oti atšķirīgs. Šajā pētījumā tika noteikts joda saturs Latvijas lielveikalos pieejamā pienā. Joda un tauku saturs 20 piena paraugos analizēts ar spektrofotometru "Varian Cary 50" un saskanā ar ISO 2446:2008. Lai analizētu piena produktu patēriṇu un tā ietekmi uz joda nodrošinājumu, tika izmantoti Centrāāās statistikas pārvaldes un grūtnieču aptaujas dati. Vidējais joda saturs piena paraugos bija 420,7 $\pm 179,6 \mu \mathrm{g} / \mathrm{L}$, ziemas paraugos tas bija mazāks nekā vasaras paraugos: 399,0 \pm 208,3 $\mu \mathrm{g} / \mathrm{L}$ un $439,3 \pm 162,3 \mu \mathrm{g} / \mathrm{L}, p<0,05$. Joda saturs vājpienā bija $490 \mu \mathrm{g} / \mathrm{L}$, pienā ar samazinātu tauku saturu 470,8 $\pm 174,8 \mu \mathrm{g} / \mathrm{L}$, pilnpienā — 382,3 \pm $192,1 \mu \mathrm{g} / \mathrm{L}$, taču, n,emot vēra l,oti lielo rezultātu izkliedi, tas nav statistiski ticams. No 2002. līdz 2014. gadam piena patēriņš samazinājās, bet jogurta un siera patēriņš pieauga. Jo augstāks piena un piena produktu patēriņš, jo augstāks bija joda saturs urīnā $\rho=0,115 ; p=0,003$. Piens un piena produkti ir svarīgi joda avoti Latvijā, un būtu jāveicina to patēriṇš. 